\title{
On the Sanskrit Manuscript of the Lalitavistara, No. 334, in the Tokyo University Library
}

\section{Koichi Hokazono}

There are six sanskrit MSS. of the Lalitavistara in the Tokyo University Library. They are listed as No. 334-9 in A Catalogue of the Sanskrit Manuscripts in the Tokyo University Library (Compiled by Seiren Matsunami, Suzuki Research Foundation, Tokyo, 1965), and a few notes on each MS. are found in it (pp. 120-1). Of the six MSS., the three, Nos. 335, 337, 338, can be regarded as complete, and the others are incomplete.

In Matsunami's Catalogue mentioned above, No. 334 is indicated as fragment, but it involves many difficulties in it. Therefore we must be careful in using it.

As for the MS. in question, the number written on each folio reaches 113 . Among them the folio Nos. 32, 94, and 112 are indicated as missing or (欠), though the indication that the folio No. 94 is missing is a mistake arisen from the fact of the folio No. 93 being numbered twice. In fact, only the two folios are missing, that is, the MS. in question consists of 111 folios.

In the matter of context, the numbering, as Matsunami's Catalogue indicates, is not correct. And the degree of its incorrectness is so tremendous that we feel a confusion in making a study of all the folios. What is worse, the MS. breaks off abruptly in context, and the lines that should follow are found in the different folios. Furthermore, there are some lacunas which are probably a transcriber's fault. The most incomprehensible thing is that the same part of passages is found in the two different places. That is to say, the transcription which corresponds to the text from p. $301, l .9$ to p. 302, $l .8$ of Lefmann's edition (S. Lefmann, Lalita Vistara I, Halle, 1902) is found in the folio Nos. 55 and 89 of the MS. No. 334 .

In it we can find the text of the chapters from the 16th to the 27th of Lefmann's edition, though the 22nd chapter is not found at all in it. Of the 18th, the 19th, the 24th, and the 25th chapters each, no missing part are found in it. And 
(9) On the Sanskrit Manuscript of the Lalitavistara (K. Hokazono)

of the 16th, the 17 th, the 26th, and the 27 th chapters, only a few missing parts are found in it. There is found in it a missing part which extends almost to three and a half pages in the latter half of the 20th chapter of Lefmann's edition. And as for the 23rd chapter, only the former half is found to be missing in it. The 21st chapter of Lefmann's edition consists of 44 pages, but the first almost 16 pages and about the 1 page in the middle are found to be contained, and the rest, to be missing in it.

The relation of the MS. and Lefmann's edition can be displayed in the following table. A circle shows the parts which are included, and a cross, those which are not included, in the MS..

\section{Lefmann's edition}

Chap. 16

Chap. 17

Chap. 18

Chap. 19

Chap. 20

Chap. 21

Chap. 22

Chap. 23

Chap. 24

Chap. 25

Chap. 26

Chap. 27

$$
\text { 237, 18-239, } 3
$$$$
239,3-243,14
$$

$243,15-252,7$

$252,8-253,22$

$254,1-260,16$

$260,17-272,7$

$272,8-289,22$

$290,1-294,22$

295, $1-298,9$

$298,10-299,14$

$299,15-315,8$

$315,8-323,6$

$323,6-324,1$

$324,1-343,12$

$343,13-357,17$

$357,18-363,22$

$363,22-369,8$

$369,9-392,6$

$392,7-402,18$

$402,19-422,7$

$422,8-423,13$

$423,13-431,8$

$431,8-431,20$

$431,20-438,14$

$438,15-444,7$

$444,7-444,21$
No. 334

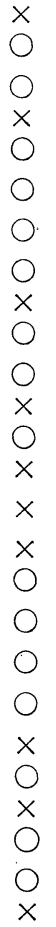

In conclusion, the context of this MS. is rather in disorder. So, in order to 
On the Sanskrit Manuscript of the Lalitavistara (K. Hokazono)

make it easy to use, it is necessary to make a comparison with Lefmann's edition.

A comparative table of Lefmann's edition and the MS. is given in the following, while the next two notes should be borne in mind.

(1) As for the first folio (1b) and the last folio (113b), there are no equivalents for them in Lefmann's edition. At present the author is unable to interpret them.

(2) Since the indication that the folio No. 94 is missing is a mistake arisen from the fact of the folio No. 93 being numbered twice, the latter folio No. 93 is rewritten as No. 94 in the table.

A comparative table of Lefmann's edition and the MS. No. 344, in the Tokyo University Library, of the Lalitavistara

Lefmann's edition

Chap. 16

Chap. 17

Chap. 18

Chap. 19
239, $3-243,14$

$243,15-249,11$

$249,11-252,7$

$254,1-257,9$

$257,9-260,3$

260, 4-16

$260,17-261,17$

$261,17-265,10$

$265,10-266,13$

$266,13-271,5$

$271,5-11$

$271,11-18$

$271,18-272,7$

272,8

272, 8-18

$272,18-273,5$

$273,5-274,3$

274, 3-21

$274,21-22$

$274,22-277,9$

$277,9-278,12$

$278,12-279,15$

$279,15-281,3$

$281,3-282,10$

$282,10-285,5$

$285,5-286,15$

$286,15-287,19$

$287,19-289,9$

289, 9-19

$289,19-22$
No. 334

$29 \mathrm{a}-33 \mathrm{~b} 1$

$33 \mathrm{~b} 1-38 \mathrm{~b}$

$20 \mathrm{a}-22 \mathrm{b3}$

$22 \mathrm{~b} 3-25 \mathrm{~b}$

$79 \mathrm{a}-80 \mathrm{~b}$

42a1-4

$42 \mathrm{a} 4-42 \mathrm{~b}$

$39 a-41 b$

$49 a-49 b$

$56 \mathrm{a}-59 \mathrm{~b}$

71a1-2

73b4-5

73a1-4

73a4-5

72b1-5

73b1-3

$71 \mathrm{~b} 4-72 \mathrm{~b} 1$

$71 \mathrm{a} 2-71 \mathrm{~b} 4$

$73 \mathrm{a} 5$

$74 \mathrm{a}-75 \mathrm{~b}$

$62 \mathrm{a}-62 \mathrm{~b}$

$83 a-83 b$

$28 \mathrm{a}-28 \mathrm{~b}$

$60 \mathrm{a}-60 \mathrm{~b}$

$26 \mathrm{a}-27 \mathrm{~b}$

$19 \mathrm{a}-19 \mathrm{~b}$

$61 \mathrm{a}-61 \mathrm{~b}$

$77 \mathrm{a}-77 \mathrm{~b} 6$

81b2-6

50a1-2 

On the Sanskrit Manuscript of the Lalitavistara (K. Hokazono)

\begin{tabular}{|c|c|c|c|}
\hline Chap. 20 & $\begin{array}{l}290,1-3 \\
290,3-5 \\
290,5-291,2 \\
291,2-292,5 \\
292,5-294,22 \\
298,10 \\
298,11-299,14\end{array}$ & $\begin{array}{l}50 \mathrm{a} 2- \\
77 \mathrm{~b} 6 \\
81 \mathrm{a} \\
50 \mathrm{a} 3 \\
47 \mathrm{a} \\
48 \mathrm{~b} 6 \\
82 \mathrm{a}\end{array}$ & $\begin{array}{l}-81 \mathrm{~b} 2 \\
-50 \mathrm{~b} \\
-48 \mathrm{~b} 6\end{array}$ \\
\hline Chap. 21 & $\begin{array}{l}299,15-300,9 \\
300,9-302,8 \\
301,9-302,17 \\
\text { (Therefore } 301,9-302,8 \text { is found on } \\
302,17-305,4 \\
305,4-306,8 \\
306,8-313,14 \\
313,14-315,8 \\
323,6-324,1\end{array}$ & $\begin{array}{l}82 \mathrm{~b} \\
55 \mathrm{a} \\
89 \mathrm{a} \\
\text { the tw } \\
86 \mathrm{a} \\
78 \mathrm{a} \\
43 \mathrm{a} \\
87 \mathrm{a} \\
96 \mathrm{~b}\end{array}$ & $\begin{array}{l}-55 \mathrm{~b} \\
-89 \mathrm{~b} \\
0 \text { places.) } \\
-86 \mathrm{~b} \\
-78 \mathrm{~b} \\
-46 \mathrm{~b} \\
-87 \mathrm{~b}\end{array}$ \\
\hline Chap. 23 & $\begin{array}{l}363,22-365,11 \\
365,11-367,2 \\
367,2-369,8\end{array}$ & $\begin{array}{l}85 a \\
76 a \\
97 a\end{array}$ & $\begin{array}{l}-85 \mathrm{~b} \\
-76 \mathrm{~b} \\
-98 \mathrm{a} 1\end{array}$ \\
\hline Chap. 24 & $\begin{array}{l}369,9-376,11 \\
376,12-388,12 \\
388,12-390,10 \\
390,10-392,4 \\
392,5-6\end{array}$ & $\begin{array}{l}98 \mathrm{a} 1 \\
103 \mathrm{a} \\
102 \mathrm{a} \\
111 \mathrm{a} \\
90 \mathrm{a} 1\end{array}$ & $\begin{array}{l}-101 \mathrm{~b} \\
-110 \mathrm{~b} \\
-102 \mathrm{~b} \\
-111 \mathrm{~b}\end{array}$ \\
\hline Chap. 25 & $\begin{array}{l}392,7-395,4 \\
395,4-400,21 \\
400,21-402,18\end{array}$ & $\begin{array}{l}90 \mathrm{a} 1 \\
51 \mathrm{a} \\
63 \mathrm{a}\end{array}$ & $\begin{array}{l}-91 \mathrm{~b} \\
-54 \mathrm{~b} \\
-64 \mathrm{a} 3\end{array}$ \\
\hline Chap. 26 & $\begin{array}{l}402,19-412,13 \\
412,13-414,2 \\
414,2-415,15 \\
415,15-422,7 \\
423,13-426,4 \\
426,4-427,3 \\
427,3-431,8 \\
431,20-438,14\end{array}$ & $\begin{array}{l}64 \mathrm{a} 3 \\
84 \mathrm{a} \\
88 \mathrm{a} \\
2 \mathrm{a} \\
7 \mathrm{a} \\
6 \mathrm{a} \\
9 \mathrm{a} \\
12 \mathrm{~b} 2\end{array}$ & $\begin{array}{l}-70 \mathrm{~b} \\
-84 \mathrm{~b} \\
-88 \mathrm{~b} \\
-5 \mathrm{~b} \\
-8 \mathrm{~b} \\
-6 \mathrm{~b} \\
-12 \mathrm{~b} 2 \\
-18 \mathrm{a} 5\end{array}$ \\
\hline Chap. 27 & $\begin{array}{l}438,15-439,5 \\
439,5-440,9 \\
440,9-441,11 \\
441,11-444,7\end{array}$ & $\begin{array}{l}18 \mathrm{a} 5 \\
93 \mathrm{a} \\
92 \mathrm{a} \\
94 \mathrm{a}\end{array}$ & $\begin{array}{l}-18 b \\
-93 b \\
-92 b \\
-96 a 5\end{array}$ \\
\hline
\end{tabular}

Another point to which we should pay attention is the connection between the MS. No. 334 and the MS. No. 339.

Contrary to No. 334, which contains the text of the 16th chapter and the followings, No. 339 covers the chapters from the 1st to the 14th; that is, the one contains the latter half of the whole text, while the other contains the former half of it. Therefore it is conceivably possible that the two MSS. may 
be united into one.

By the investigation of No. 339, we found that it does not have so many confusions as No. 334. We can point out a few remarkable faults in No. 339 as follows; a fair reversal of lines on the folio Nos. 143b-144a (but the transcriber is aware of this error), and a reversal of the first half and the second half in the folio No. 152 (152a and 152b). At any rate, only a few confusions can be found in No. 339.

However, it should be admitted that the last folio of No. 339 (the folio No. 159) rightly belongs to No. 334 . The reason why we say this is that the context of the MS. No. 339 breaks off abruptly at the folio No. 158, the 14th chapter being left unfinished, and at the next folio. No. 159 appears the text of the 21st chapter, and that the lines of the folio No. 159a is to be connected directly with the lines of the folio No. $96 \mathrm{~b}$ of No. 334. Moreover, the context of No. 339 being broken off again at the first line of the folio No. 159b, suddenly appears the text of the 27 th chapter, which is to be connected with the interrupted lines in the folio No. 96a of No. 334, and so we find that the unfinished text of the last chapter (the 27th) in the folio No. 96a of No. 334 is brought to completion in the folio No. $159 \mathrm{~b}$ of No. 339.

Therefore it is admitted that the folio No. 159 of the MS. No. 339 originally belongs to the MS. No. 334. And if it undoubtedly belongs to No. 339 for some reasons unknown us, the two MSS. (No. 334 and No. 339) must have been an united MS. in the beginning. Being found in Matsunami's Catalogue the abbreviations which indicate the fact that No. 334 was collected by Ekai Kawaguchi and No. 339 by Junjirō Takakusu, this problem acquires a deeper significance. (Assoc. Professor, Kagoshima College of Economics) 